\title{
P. Ramlee and Neorealism
}

\author{
By Jan Uhde
}

Spring 2015 Issue of KINEMA

\section{P. RAMLEE AND NEOREALISM}

P. Ramlee was one of the legendary filmmakers of Southeast Asia a multifaceted artist considered to be the most important creative asset of the "golden age" of cinema of Singapore and Malaysia in the 1950s and 60s. Born Teuku Zakaria bin Teuku Nyak Puteh in Penang, the Straits Settlements (now Malaysia) in 1929, he spent most of his professional career in Singapore, then a regional film production centre, working for the Shaw Brothers' Malay Film Productions. In 1964 he returned to Malaysia to work for its fledgling Merdeka (Independence) Film Productions in Kuala Lumpur. During his lifetime, P.Ramlee directed 34 features and acted in more than 60 films.

The singular contribution of P. Ramlee to the development of cinema and other art forms of Singapore and Malaysia is unquestioned. In his time, he was tremendously popular and today, four decades after his premature death in 1974 at the age of 44, he has become an icon with a considerable cult following by both the old and young generations in Malaysia, Singapore, Indonesia and beyond.

From among P.Ramlee's numerous and diverse artistic activities, which included being a film director, actor, writer, producer, editor, singer, composer, songwriter and publisher, it is his filmmaking career which is the most conspicuous today. His films embraced and synthesized almost all the facets of his creative spectrum and allowed him to display his talents in story-telling, directing, acting, singing and composing. Not without reason, this universal artist is often called the Asian Charlie Chaplin. He is, however, almost un known in Europe and America, beyond narrow professional circles.

Like most of his activities, the filmmaking of P.Ramlee was a colourful affair, blending the director's creativity with outside influences and stimuli. He integrated elements from diverse sources including his Malay heritage, Singapore's cosmopolitanism, India's old culture and European cinema which he fused into a unique personal style. This helped to give the Singapore cinema of the 1950s and 60s and later the Malaysian national film production their distinctive identity and flavour still enjoyed by audiences today.

The stylistic attributes of P.Ramlee's movies display an eclectic mix of popular genres, including contemporary social drama, comedy, historical costume film and musical. He was, as the American film scholar Tim White pointed out, "distinguished from other contemporary Malay films through his assimilation of far-reaching influences". ${ }^{(1)}$ The most frequently cited influences - both narrative and stylistic - are those of Indian cinema and Malay traditional bangsawan theatre, with their characteristic emotion-charged plot and the ubiquitous music and song. Supported claims have been made pointing to the less obvious impact of Japanese cinema the films of which, including some aesthetically important works, were prominently distributed on the Malay Peninsula and in Singapore during the Japanese occupation. ${ }^{(2)}$

An undeniable element of P.Ramlee's film style was realism, especially in his family dramas.. Realism was in evidence already in the director'sfirst feature The Trishaw Puller (Penarik Becha), ${ }^{(3)}$ made in 1955. ${ }^{(4)}$ The film was, without doubt, a great opportunity for the young director - Ramlee was twenty-six at the time he became the film's director, scriptwriter and star. This meant an unusual measure of control for the filmmaker, who was then a salaried employee of the Shaw Brothers' Malay Film Productions, a company which, together with the Cathay-Keris, was one of the two most important and most prolific production companies in Singapore after World War II.

The creative freedom the filmmaker was given and which he knew how to exploit, doubtlessly contributed to the film's artistic accomplishment as well as its box-office success. Indeed, The Trishaw Puller became one of P.Ramlee's signal achievements and also the turning point of his career. In this film, he moved away from the Indian romantic tradition to the contemporary social drama which reflected the lives of common people and their everyday concerns. From his debut and throughout his entire artistic career, P.Ramlee's focus was on the ordinary citizen. This was one of the secrets of the artist's enduring popularity. 
The Trishaw Puller, which also contains the first song that P.Ramlee composed and one of his most admired, "Azizah", was chosen as the Best Malay Film in 1956. ${ }^{(5)}$ It launched the director's career and built his reputation as Malaya's ${ }^{(6)}$ and Singapore's most important film artist. In his speech of acceptance, P.Ramlee told the audience: "Ever since I started my career in the celluloid world, I have one thought in mind - to create something new and to stand out amongst the locally produced films. It is you, whom I want to satisfy".

The film, shot in Singapore, is thematically anchored in contemporary urban surroundings and confronts traditional values with the inevitable pull of modernity which characterized the regional post-WWII life. Yet, perhaps more than in his other films, the filmmaker focuses on the social issues of the time. The story brings together a poor trishaw driver Amran (P.Ramlee) and Azizah (Saadiah), a girl from a rich family. Using the familiar form of melodrama, the director moves beyond the conventional boundaries of the genre by offering a thinly veiled discourse on wealth and poverty, and life's values.

Being forced to endure numerous trials and humiliations, the destitute Amran demonstrates by his selflessness that there is another kind of 'wealth' outside of the material one: he not only shields Azizah (then a trishaw fare unknown to him) from a looming assault by the crooked Ghazali and his friends; he also refuses to exploit the obligation Azizah subsequently feels towards him. In the final confrontation with the now unmasked Ghazali, he saves Azizah and her family from grave danger - again without any claim for compensation. Despite his evident love for Azizah, he only asks to be re-hired by the family as a trishaw man.

Moreover, his selfless example helps to bring about a significant change: Marzuki, Azizah's father, a rich man who had until then, respect only for things of material value, realizes his mistake and promises to repent. He says about Amran: "Poor but rich in values". He declares him his future son-in-law and vows to help him with his education. Such a turnaround may seem too melodramatic and simplistic to today's audiences, but it will be understood differently when seen in the historical context of the film's release period, the 1950s. Malay film production was still in its infancy at the time and the audiences were less sophisticated then. Besides, it was P.Ramlee's intentions to turn out films that could be easily understood by most viewers.

P.Ramlee's social commentary lifts The Trishaw Puller above conventional melodrama. In his biography of P.Ramlee, the late British writer and broadcaster James Harding observes: "Social criticism is implied in the stark contrast between Amran's poverty-stricken existence and the easeful life of Marzuki's rich family". (7) The film offers the viewer more than just a well-constructed plot, suspense, and emotional roller-coaster. It adds a simple but honest humanist message about respect and caring for others regardless of wealth and social status. In fact, the father (Marzuki) only gains a true human face when he realizes the error of his ways. Moreover, the union of the young loving couple in the film's final scene, a part of the generic formula, is virtually eclipsed by Marzuki's discovery of life's true values.

Such an approach in dealing with social issues was significant in a country which had recently been through the trauma of the war and the Japanese occupation. Social inequality was widespread, while far reaching political and social changes were taking place: the end of the colonial period and the dawn of independence. ${ }^{\left({ }^{8}\right)}$ As Harding noted, the residents of Malaya "...had to deal with a communist insurgency, modernisation, and questions over the future relationship between Singapore and Malaya". (9) P.Ramlee himself was born into a relatively poor family and was sensitive to social inequality.

Another social issue which prominently figures in The Trishaw Puller is that of education. Along with other young girls, Azizah attends evening sewing classes. She suggests that Amran too improve his situation through education. This effort is temporarily interrupted by the confrontation with Ghazali but eventually resurfaces at the end of the movie when Azizah's father himself promises to take care of his future son's-in-law education. Education is suggested as a way out of poverty.

The Trishaw Puller also achieved an unusual success in real life: through its popularity, it helped to improve the social status of one of the country's most neglected and exploited people: the trishaw riders, whose status in the community rose significantly as a result of this film. A societal effect such as this would alone make P.Ramlee's debut a remarkable film - movies' influences upon real life are quite rare. ${ }^{(10)}$

The Trishaw Puller was not the only film made by P. Ramlee in which the director brought up social issues of the period. His 1962 drama My Mother-in-Law (Ibu mertuaku) in which the filmmaker starred as he did in 


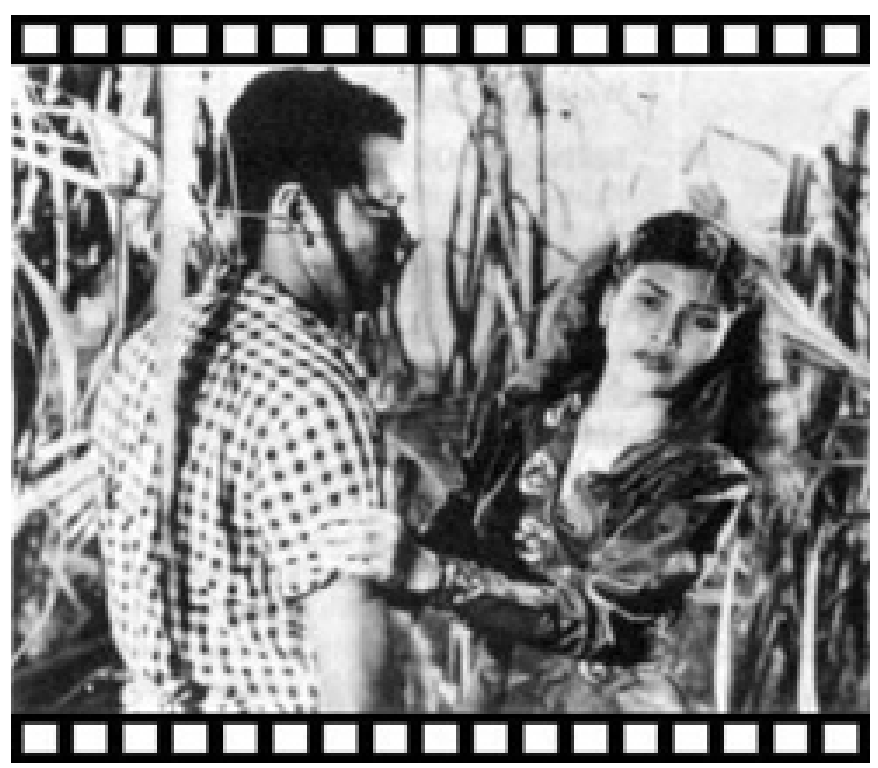

Figure 1: P.Ramlee in his The Trishaw Puller, 1955

most of his films, again points out to the issue of social inequality reflected through an informal class system. The well-off mother of the young Sabariah Mansoor (Sarimah) tries to prevent her daughter's marriage to the talented but penniless saxophonist Kassim Selamat (P. Ramlee). Her intrigues eventually result in a tragedy (a denouement differing from the positive resolution of the social conflict in The Trishaw Puller). My Mother-in-Law, perhaps P.Ramlee's best film, is deservedly a classic in Singapore and Malaysia's golden era of cinema.

Stylistically, The Trishaw Puller attracts attention through the use of a realistic perspective, until then rare in Singapore Malay language cinema. The director frequently includes documentary city scenes: real streets, real people, real noises. The viewer is presented with incidental, unrehearsed and unexpected situations surrounding the main action. In The Trishaw Puller, this atmosphere is introduced in the establishing shot or rather establishing scene: a juxtaposition of fast-moving cars, buses crossing a busy bridge, a magnificent seashore and a park with swiftly moving traffic in the background.

Getting closer to the actual plot, the viewer is offered a dramatic tracking shot, with the camera following a newspaper boy running through a busy city street shouting and waving a fresh paper edition over his head. By the curbs, we can glimpse a few parked trishaws - the first visual cue of the story about to unfold.

This skilfully framed tracking shot moves past people standing in front of shop houses. A short glimpse of the "Singapore Cold Storage" grocery store sign establishes the geographical setting of the story. The second visual cue foreshadowing the story shows the accidental meeting of two of its main characters: Marzuki hails a trishaw and orders the driver to take him home. At first, we see only the trishaw's back. Slowly, the camera reveals the character's face: it is Amran, the film's protagonist, played by P.Ramlee.

The narrative of The Trishaw Puller centres on a relatively narrow circle of characters: Amran, Azizah, Ghazali and Marzuki. They are played by professional actors, together with a few secondary characters. Yet in the background, we can observe numerous other people, played out by non-professional performers or simply accidental bystanders such as those in the pre-credit scene who look on curiously as the newspaper boy runs down the street. This injection of semi-documentary content lends the film an atmosphere of authenticity. Also, in the introductory scene, when Marzuki is looking for a trishaw, he is shown walking out of a real Chinese grocery store into a real street.

Another scene filmed on location instead of in the studio, is the roadside accident. The stingy Marzuki is looking for a cheap trishaw. He gets into an argument with one of them over the price and assaults him unsuccessfully. As he attempts to pick up his cane which had been thrown onto the open road during the 
squabble, he is hit by a passing car. The driver of the car is the swindler Ghazali. The scene was evidently staged, but the surroundings were real.

The relatively long beach sequence was constructed similarly. Azizah and a group of girlfriends arrive at the beach by trishaw with Azizah being driven by Amran. They picnic, some of them play merrily in the sea, while the trishaw drivers wait for them nearby. The girls start singing and the trishaw boys join them. As if lifted by the lyrical melody of the song, the camera pans across the palm trees.

Here, in the privacy of the palm tree forest branches, Azizah and Amran meet for the first time in private, unobserved by others. "Do you know where happiness in life lies?" Azizah asks Amran. When Amran points out to his low social status, Azizah, the rich man's daughter, reminds him: "Rich and poor are the same. Wealth isn't everything". Much of this sequence is filmed at a deserted beach.

Some other scenes of the film, including the assault on Amran by Ghazali's thugs, are also filmed outdoors, mostly in open spaces with shrubs or trees. Likewise, My Mother-in-Law includes realistic scenes filmed on location in and around authentic construction sites in the city.

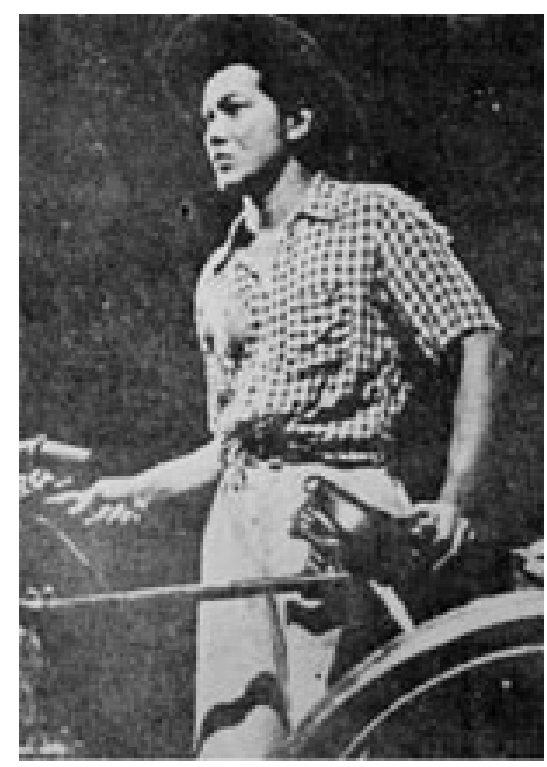

Figure 2: P.Ramlee in his The Trishaw Puller, 1955

These stylistic elements of The Trishaw Puller, My Mother-in-Law and other P. Ramlee films - particularly their focus on contemporary social issues, the relatively frequent use of on-location shooting, the combination of professional and non-professional actors, point to the Neorealist influence on the filmmaker.

There is a also a certain affinity between P.Ramlee's trishaw driver Amran and the unemployed worker Antonio Ricci from the famous Neorealist film The Bicycle Thieves made in 1948 by Vittorio De Sica. Both protagonists are honest, humble people slowly being crushed by the burden of interminable poverty. Both characters use bicycles, or modified bicycles to earn their living. Antonio's bike is stolen, while Amran's trishaw is demolished by a gang of thugs and he himself is beaten up. None of the two is demanding anything more than decent work and an honest living. Both live in an anonymous, big city and have family members dependent on their earnings - wife and son on the one hand, and an elderly mother on the other.

The Trishaw Puller's simple plot, too, recalls a Neorealist perspective; although it does not seem to be much improvised, its explicit social concerns point towards Neorealism. Even its studio settings are simple: there are no lavish interiors either. One could argue that the film is too melodramatic and eclectic to be connected with Neorealism. But melodrama was not strange to Neorealist films (compare scenes with the Nazis in Roberto Rossellini's Rome: Open City) as well as to a number of "late-neorealist" Italian films, including the 1949 feature Bitter Rice (Riso amaro) and Roma at 11 am (Roma ore undici, 1952), both directed by Giuseppe De Santis. However, in The Trishaw Puller, My Mother-in-Law and other films, the melodrama 


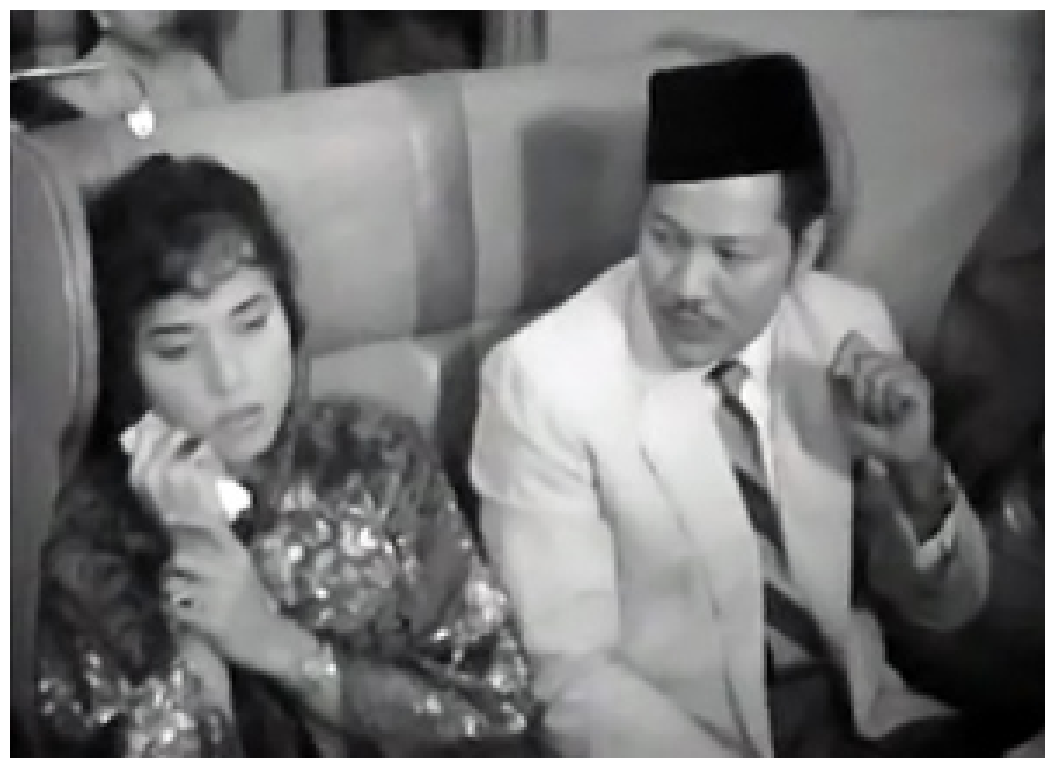

Figure 3: P.Ramlee and Sarimah in his My Mother-in-Law (1962)

tendency is compensated by P.Ramlee's evident sincerity with which he presents social problems and his desire to communicate with the average viewer.

The realist element of The Trishaw Puller represented by the on-location scenes is sometimes downplayed: for example, William van der Heide, the author of the comprehensive study of Malaysian cinema, suggests that The Trishaw Puller "...fits more easily into the Bangsawan performance tradition and frequently betrays its predominantly studio setting, despite its documentary introduction to Singapore in the pre-credit sequence...." (11) Elements of the Bangsawan performance tradition are indisputably present in P. Ramlee films as this was the widespread model of Malay-language cinema before P. Ramlee. It was P.Ramlee, however, who introduced the social (melo)-drama with realistic components into these films, putting the Singapore Malay language film of the 1950 s and 60 s on a different path.

In The Trishaw Puller, there are a total of five on-location scenes in the film: 1. the pre-credit sequence (city); 2. the accident scene; 3. the beach outing; 4. the assault of Amran; 5. the search for Amran. They amount to a total of 18 minutes of the film time, or about 18 percent of the movie's length. Moreover, in these scenes, the director focuses on action more than on dialogue; also, he supports this by framing and editing.

The lifespan of Italian Neorealism is usually demarcated by the release of Roberto Rossellini's Rome Open City in 1945 and Vittorio De Sica's Umberto D. in 1952. ${ }^{(12)}$ One of the greatest neorealist films, De Sica's Bicycle Thieves, was released approximately mid-stream. Besides its own artistic merits, Italian Neorealism has become one of the most influential movements of the entire history of the motion pictures.

It is this truly global influence of Neorealism which is interesting in the context of this enquiry: European (French New Wave, Greek cinema), North American (Québec Direct Cinema), Latin American (Brazilian Cinema Nôvo and early post-revolutionary Cuban cinema), several African productions and Asian cinemas (India's Satyajit Ray, Indonesia, the Philippines) were, in different historical periods and in different ways, affected by this great movement. According to the American scholar Robert Sklar, when "...films such as Bicycle Thieves and Rome Open City reached countries in Asia, Africa and Latin America, they struck aspiring filmmakers as revelations".(13) In Japan, remarks the film historian Mira Liehm, "...the neorealist films provoked a real explosion in the development of cinema, linking up with pre-war Japanese realism, mainly with the films of Yasujiro Ozu". ${ }^{(14)}$ Considering the pre-WWII Japanese film, particularly the work of Ozu during that fertile period, it may be successfully argued that the Japanese pre-war realism is a kind of proto-Neorealism. 


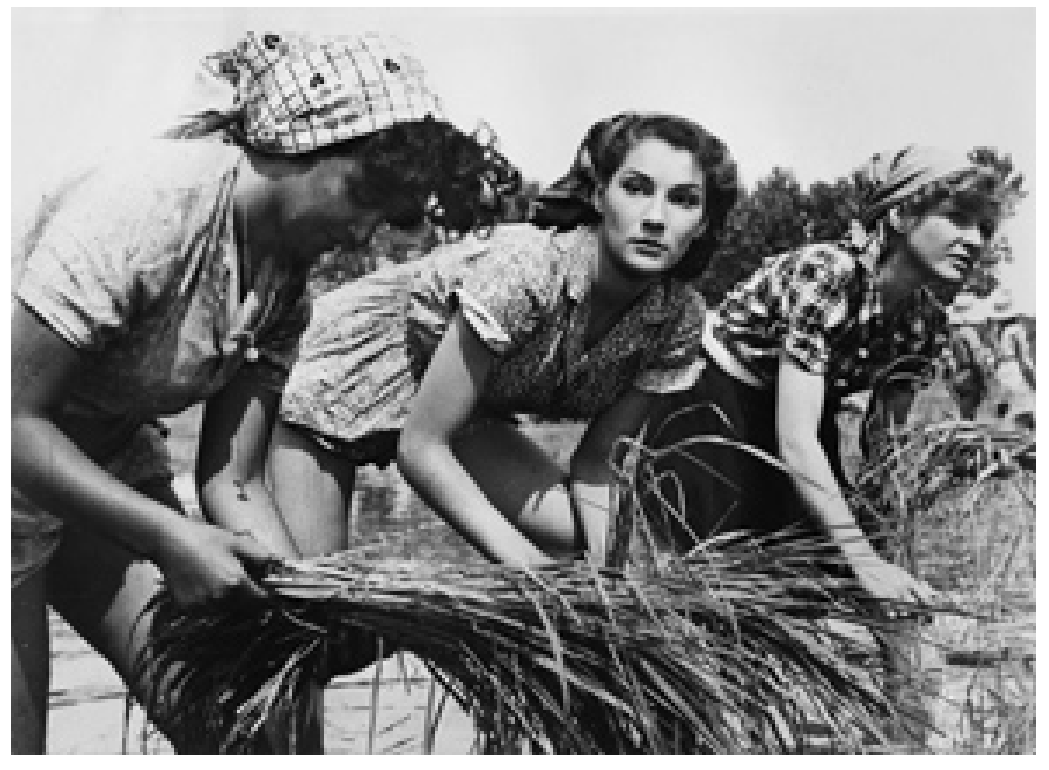

Figure 4: Bitter Rice by Giuseppe De Santis, 1949

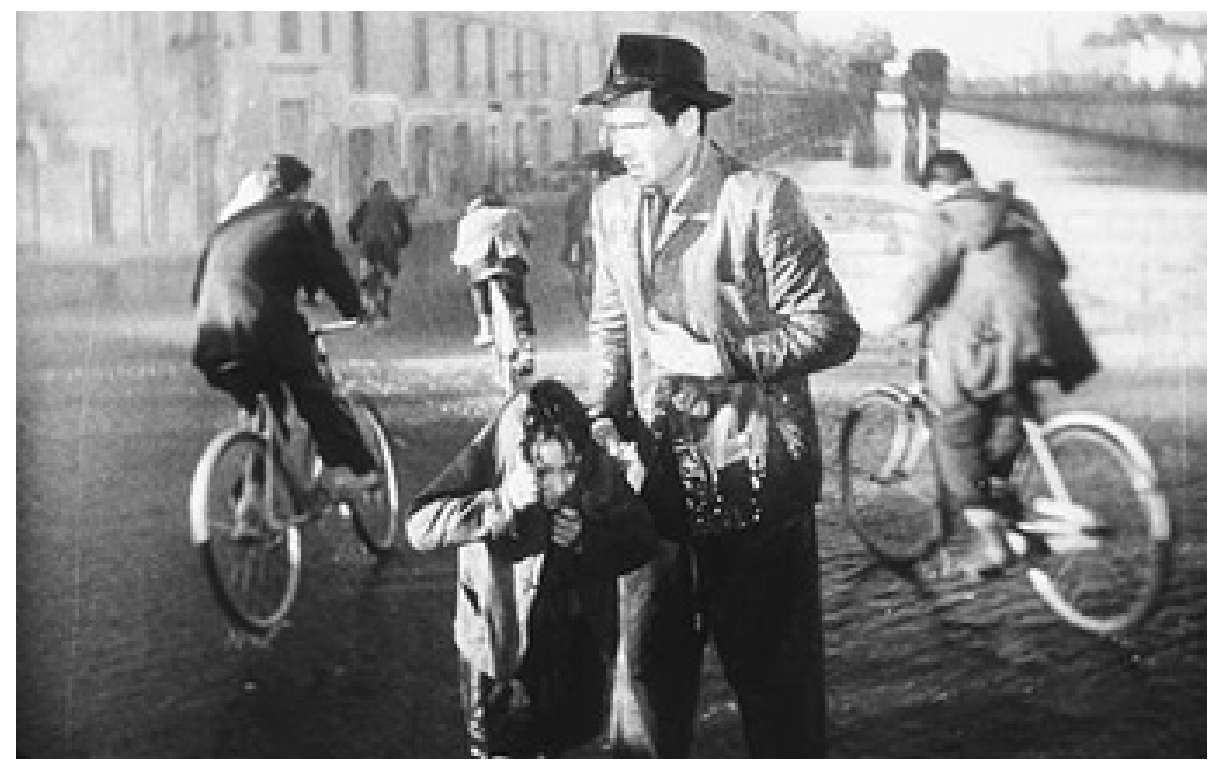

Figure 5: Bicycle Thieves by Vittorio DeSica, 1948 
It is not the intention of this article to examine in detail the background of this momentous global influence, but it may be useful to bring up the following: The Italian Neorealism was a movement fairly closely related to Marxist ideology. Marxism was, for a long period after the World War II, a dominant ideology in most emerging countries of the non-Western parts of the world and it was favoured by many intellectuals and artists there. Moreover, the principal themes of Neorealism - the struggle for national liberation and the questions of poverty and social injustice stood in the centre of the political and economic concerns in many countries of the so-called Third World. In addition, the audio-visual language of cinema with its emotionally powerful imagery, was seen as a useful medium for addressing illiterate and semi-literate masses - much more efficient than the written word.

This was not the first time the motion pictures were seen from this viewpoint. Already at the beginning of the $20^{\text {th }}$ century in the United States, masses of semi-literate immigrants from all over the world with little command of the English language crowded the early 'nickelodeon' cinemas fuelling the rapid expansion of the fledgling moving pictures industry. About two decades later, similar social conditions helped the Soviet Russian government address factory proletarians and peasants with its propaganda messages. For a generation of young Soviet filmmakers - Eisenstein, Pudovkin, Dovzhenko and others - this became an artistic laboratory and a golden opportunity that gave birth to the famous Soviet classical cinema of the 1920s.

The end of WWII, which saw the end of the colonial empires and the rise of many new countries - also witnessed the birth of new national motion picture productions. Marxist theory was perhaps fashionable there, but it was the realistic style as such that attracted the filmmakers of the new film-producing countries the most. It offered artists an opportunity to comment on the burning political and social problems of their young countries in a new way, via a powerful mass medium. The big Italian Neorealist themes - struggle for liberation and independence, questions of poverty and social inequality - became universal. In the words of the well-known American film historian David A. Cook, "Neorealism was the first postwar cinema to liberate filmmaking from the artificial confines of the studio and, by extension, from the Hollywood-originated studio system".(15)

Following Zavattini's theoretical canon, Italian Neorealism was supposed to observe three rules: on-location shooting, the use of non-professional actors and improvised script based on actual events. As artists generally dislike dogmas, these 'commandments' were rarely rigorously followed, even in Italy: for example, nonprofessional actors were often used together with professionals; on-location shooting was combined with studio scenes; the 'script improvisation' was relatively freely interpreted.

Such flexibility suited filmmakers in non-Western countries who were responding to economic, social and cultural conditions different from those of their European colleagues. One feature of the new Italian style had a particular appeal to low-budget film producers in the economically underdeveloped world. Neorealism was a much more economical production style than traditional studio-based production. Most of the new countries had underdeveloped infrastructures - insufficient or no film studios. This was a situation comparable to that of the devastated post-war Italy which prompted the Neorealist Roberto Rossellini to shoot indoor scenes in ordinary flats, using existing light and low-quality or expired film stock - quickly turning such 'deficiencies' into indispensable aesthetic attributes of the Neorealist imagery.

The most widespread impact of any Neorealist film - both at home and internationally - was most probably that of De Sica's 1948 Bicycle Thieves (Ladri di biciclette). On the Italian home ground, this famous feature became the source of Maurizio Nichetti's Icicle Thief (1989) and inspired Gianni Amelio's Stolen Children. Elsewhere, it was remade by the Chinese director Wang Xiaoshuai as Beijing Bicycle (2001). Bicycle Thieves have been touring the world for over five decades now, inspiring through its humanist message and simple style generations of filmmakers, including the Iranian Majid Majidi and his 1997 movie Children of Heaven. ${ }^{(16)}$

In India, Italian Neorealist films were known at least since 1951: they were shown that year at the First International Film Festival in Bombay. The London-based film historian and filmmaker Sangeeta Datta wrote: "...the influence of Italian neo-realism in Indian cinema was already evident in Bimal Roy's Do Bigha Zameen (Two Acres of Land, 1953)"."(17)

Not surprisingly, the Italian Neorealism and especially Bicycle Thieves had a great impact on the work of 
the Bengali film master Satyajit Ray, ${ }^{(18)}$ arguably the first Neorealist auteur in Indian Cinema - particularly on his 'Apu trilogy' made in the 1950s: Pather Panchali (1955), Aparajito (1957) and Apur Sansar (1959). According to Cook, "Ray has claimed that a single viewing of De Sica's Ladri di biciclette in London in 1950 led him to film his trilogy according to neorealist methods". (19)

In the early 1950s, most of Shaws' Malay Film Productions' directors, such as B. S. Rajhans, K. M. Basker, L. Krishnan, B. N. Rao and S. Ramanathan, as well as other film professionals, were Indian; they exercised a strong influence upon the local production. In close co-operation with them, P. Ramlee started his career, built a reputation as a versatile actor, and eventually director.

Under these circumstances it is hard to imagine that P.Ramlee, an enthusiastic film viewer who had worked at Singapore's closely-knit Jalan Ampas Studio for seven years prior to his feature debut in 1955, and was in regular contact with the Indian directors there, would be ignorant of the Neorealist cinema and its concepts.

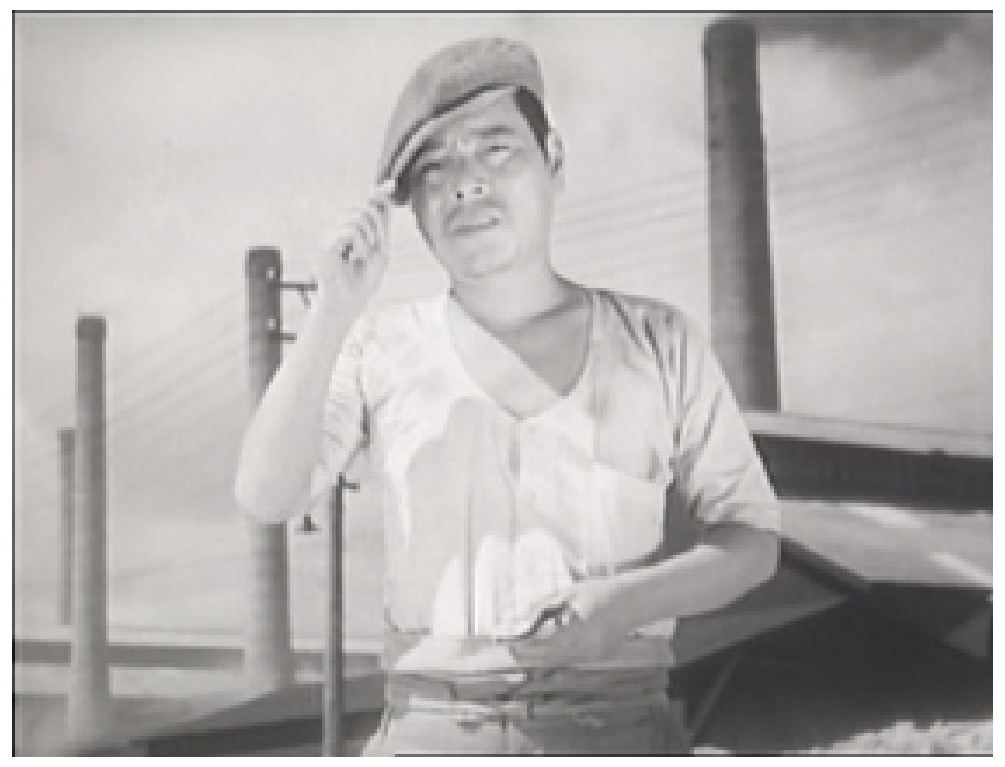

Figure 6: An Inn in Tokyo by Ozu Yasujiro, 1935

Despite the presence of Neorealist elements in P.Ramlee's first feature, The Trishaw Puller is by no means a Neorealist film - certainly not a Neorealist film of the Italian type. P.Ramlee was an eclectic filmmaker, much like his creative personality.

The Trishaw Puller displays a variety of stylistic characteristics: from the generic point of view for example, it is a melodrama, ${ }^{(20)}$ its plot significantly influenced by the Indian tradition. Many of its scenes are typical studio sets, including the 'faked' outdoor lyrical scene when P.Ramlee is singing his famous "Azizah".

The most conspicuous non-realistic ingredients in P.Ramlee's first feature - and in practically all his films which followed - are the musical interludes which from time to time interrupt the action and bring the narrative to a virtual standstill. Such lyrical moments offer the viewer relief from the tensions of the dramatic action while commenting on the events. They are the film's chorus, to use the term from the classical Greek drama. P.Ramlee successfully blends the realistic with the expressive, the epical with the lyrical. These poetic interventions which interrupt the action are rooted in the Malay bangsawan theatrical performance and still characterize certain types of contemporary Asian cinema such as Bollywood.

This blending of techniques and genres should not by itself be interpreted in a negative way. The development of artistic styles, in film and other art forms is often the result of mutual, often conflicting influences. For example, the Italian Neorealism was influenced by the French 'poetic realism' of the late 1930s. Novice Italian filmmakers - and future Neorealists - such as Michelangelo Antonioni and Luchino Visconti first assisted their more experienced French colleagues ${ }^{(21)}$ - in the same way that the young P.Ramlee was assistant director to his Indian film mentors. P.Ramlee's eclecticism - including the Neorealist legacy - reflects the 
multifaceted and multi-ethnic situation in which he lived and worked: he, a Malay, having experienced Japanese occupation, working in Singapore, then a British colony, in Chinese-run studios under Indian directors. He drew from a variety of traditions, both local, regional and international, filmic, theatrical and musical. Neorealism became one of P.Ramlee's important inspirations. The result is his unique and inimitable personal style.

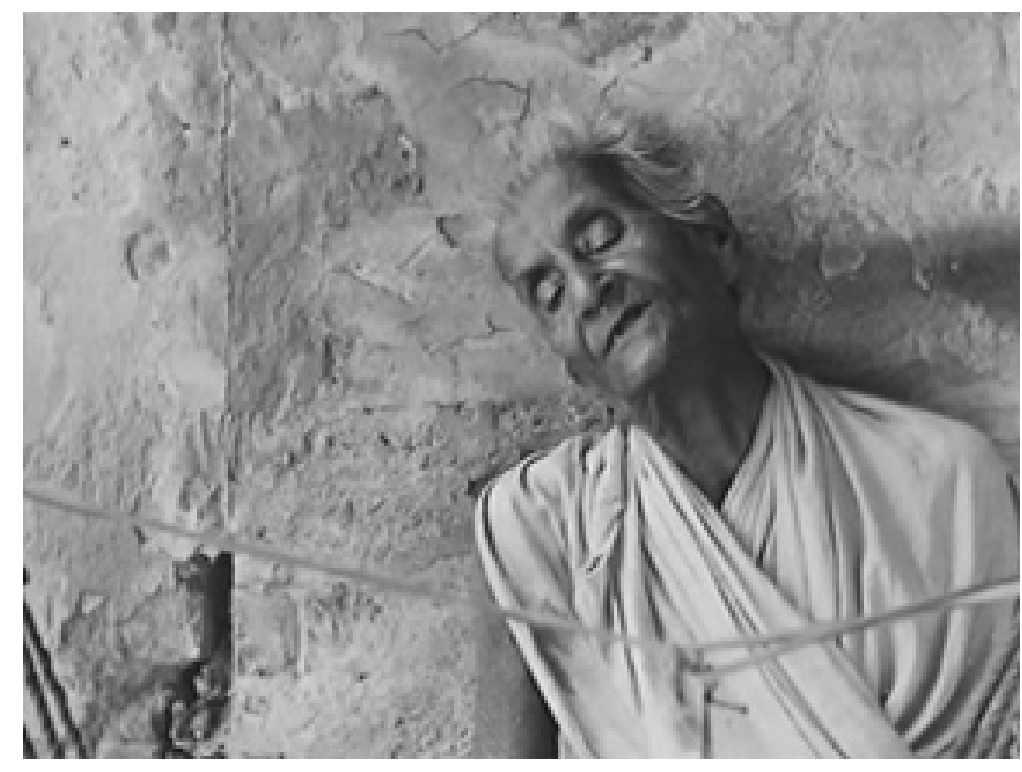

Figure 7: Pather Panchali by Satyajit Ray, 1955

\section{Notes}

1. Timothy White, "P.Ramlee's Cinema of the Kampong," National University of Singapore,http://216.239.51.104/search?q=c 8. (1 September 2014.)

2. A detailed discussion of Japanese film influences upon P.Ramlee in: Timothy White: "Historical Poetics, Malaysian cinema, and the Japanese Occupation", Kinema 6, Fall 1996, 4-23.

3. The film's alternative titles are Penarik Beca, The Trishaw Driver and The Rickshaw Driver (the latter is semantically incorrect, as the trishaw is a vehicle different from rickshaw).

4. The Singapore-based French film historian Raphaël Millet mentions the Japanese film Jin Rickshaw, later adapted in Hong Kong, as a source of inspiration for P. Ramlee's The Trishaw Puller. Raphaël Millet, Singapore Cinema, Didier Millet, Singapore 2006, p. 49.

5. Best Malay Film, by Utusan Film and Sport Magazine, Malaya (1956).

6. Today's Malaysia.

7. James Harding and Ahmad Sarji: P.Ramlee: The Bright Star (Subang Jaya: Pelangor Publications, 2002), p. 98.

8. Malaya gained independence from Britain in 1957.

9. Timothy P. Barnard, "The Times They Were a Changin'", The Star Online, http://thestar.com.my/lifestyle/story.asp?file= (8 October 2010.)

10. One of the few comparable examples in recent years would be the 1993 feature Sopyonje by the South Korean master director Im Kwon-taek, which told the captivating story of a pansori singer and subsequently 
managed to revive in the country this half-forgotten traditional Korean musical art form.

11. William van der Heide, Malaysian Cinema, Asian Film, Amsterdam University Press (Amsterdam, 2002), p. 176.

12. There were precursors to the Neorealist style produced in the early 1940s, including Luchino Visconti's Obsession (Ossessione, 1942); however, they are not considered to be part of the Neorealist mainstream.

13. Robert Sklar, Film: An International History of the Medium, Prentice Hall: Upper Saddle River, New Jersey, 2002, p. 268.

14. Mira Liehm, Passion and Defiance, Berkeley: University of California Press, 1984, p.130.

15. David A. Cook, A History of Narrative Film, Norton: New York, 1996, p. 438.

16. For example, many international successes of the contemporary Iranian cinema reflect neorealist inspiration, including Majid Majidi's Color of Paradise (1999) and Father (1996); Mohsen Makhmalbaf's Cyclist (1987), Jafar Panahi's White Balloon (1995), just to name a few.

17. Sangeeta Datta, Shyam Benegal (London: BFI Publishing, 2002). Displayed online http://www.bfi.org.uk/showing/nft/fe (3 September 2003).

18. Yoram Allon: "Although Ray was a co-founder of the Calcutta Film Society in 1947, which exhibited American, European and Soviet films, it was during the Indian Film Festival in Calcutta in 1951 that Indian audiences first saw Bicycle Thieves (1948) and other landmark neo-realist films. De Sica's film, which Ray actually saw in London, was to be an enormous influence upon him, and along with his love of Kurosawa's Rashomon (1951), effectively ensured he become a film-maker". http://www.kamera.co.uk/reviews_extra/pather_panchali.php (2 January 2015.)

19. Cook, p. 438.

20. It should not be forgotten, however, that many Neorealist films were also quite melodramatic, including Rossellini's Rome Open City.

21. Michelangelo Antonioni worked as an assistant to Marcel Carné on his visiteurs du soir (1942); Luchino Visconti assisted on Jean Renoir's Une partie de campagne (1936, released 1946).

\section{References}

\section{Literature}

Cook, David A. A History of Narrative Film. New York: Norton, 1996.

Gabriel, Teshome H. "Towards a critical theory of Third World films," in Jim Pines and Paul Willeman, eds. Questions of Third Cinema. London: British Film Institute, 1989.

Harding, James and Ahmad Sarji. P.Ramlee: The Bright Star. Subang Jaya: Pelangor Publications, 2002.

Liehm, Mira. Passion and Defiance. Berkeley: University of California Press, 1984.

Millet, Raphaël. Singapore Cinema. Singapore: Didier Millet, 2006.

Sklar, Robert. Film: An International History of the Medium, Upper Saddle River, New Jersey: Prentice Hall, 2002.

Uhde, Jan and Yvonne Ng Uhde. Latent Images: Film in Singapore, $2^{\text {nd }}$ Edition. Singapore: National University of Singapore, 2010.

van der Heide, William. Malaysian Cinema, Asian Film. Amsterdam: Amsterdam University Press, 2002. 


\section{Reports}

Photo credits: Penarik becha, Ibu mertuaku: Malay Film Productions; Riso amaro: Lux Film; An Inn in Tokyo: Shochiku Eiga; Ladri di biciclette: Image Entertainment; Pather Panchali: Govt. of West Bengal.

\section{Author Information}

Jan UHDE is Professor Emer. (Film Studies) at the University of Waterloo, Ontario, Canada. Born in Brno, Czech Republic. Graduated (MA) from the Faculty of Arts, Masaryk University, Brno; PhD received at the University of Waterloo, Ontario, Canada. He taught at the University of Waterloo (1970-2012) where he founded a General and Honours BA program in Film Studies at the Department of Fine Arts.

Publications: Latent Images: Film in Singapore Second edition, with Yvonne Ng Uhde (Ridge Books, National University Press of Singapore, 2010); Latent Images: Film in Singapore, with Yvonne Ng Uhde (Oxford University Press, 2000); Latent Images: Film in Singapore CD-ROM (2003, co-author); Vision and Persistence: Twenty Years of the Ontario Film Institute (University of Waterloo Press, 1990) and Ontario Film Institute Programming Activities Index 1969-1989 (Toronto: Ontario Science Centre, 1990). He co-edited the Place in Space: Human Culture in Landscape (Proceedings from the Second International Conference of the Working Group "Culture and Landscape" of the International Association of Landscape Ecology, Pudoc Scientific Publishers, Wageningen, Holland, 1993). Jan Uhde has published articles and reviews in several countries (including Canada, USA, Germany, Italy), participated in international juries at film festivals and presented papers at international conferences in North America and Europe. In 1998/99, he was a visiting researcher at the School for Film and Media Studies, Ngee Ann Polytechnic, Singapore.

His professional and research interests focus on Singapore cinema; the identification and distancing mechanisms of the film viewer; the non-authored modifications and manipulation of films; and specific aspects of film history, including the Central European cinema.

He founded KINEMA in 1993. 